\title{
The Effect of Marital Locus of Control on Marital Adjustment of Couples
}

\author{
Dr. Javnika Sheth
}

Keywords: Marital Locus, Adjustment

\section{INTRODUCTION:}

\section{The concept of locus of control:}

Locus of control is a concept first developed by Phares (1957) relating to beliefs about internal versus external control of reinforcement. Since the advent of Rotter's social learning theory, locus of control has become an important variable in psychological researches, the construct known as 'locus of control' first came into prominence with the publication of a monograph by Rotter (1966). He also presented the scale to assess locus of control.

Locus of control refers to generalized expectancies of the individual for internal vs. external control of reinforcement. The concept of locus of control describes the degree to which an individual believes that reinforcements are contingent upon one's own behavior.

Internal control refers to the perception of an event as contingent upon one's own behavior, capacities or one's relatively permanent characteristics. External control, on the other hand, indicates that a positive or negative reinforcement following some action of the individual is perceived as not being entirely contingent upon his or her own action but the result of chance, fate, or luck or it may be perceived as under the control of powerful others and unpredictable because of the complexity of forces surrounding the individual (Anastasi, 1988). If we believe that we are the cause of most events, we have a highly internal locus of control. If we believe that most events in our life are caused by luck, fate or powerful others, we have a highly external locus of control. (Morgan et.al.1986).

\section{Marital locus of control: Its operational definition:}

Locus of control studies in the context of interpersonal relationship is rather scanty. The empirical studies conducted on locus of control and marriage have centered on the relationship between locus of control and marital satisfaction and stability and problem solving behavior in marriage (Doherty, 1983).

${ }^{1}$ Head in psychology, Shah K S arts and V M Parekh comm. college, Kapadwanj, kheda, Gujarat, india

(C) 2015, J Sheth; licensee IJIP. This is an Open Access Research distributed under the terms of the Creative Commons Attribution License (http://creativecommons.org/licenses/by/2.0), which permits unrestricted use, distribution, and reproduction in any Medium, provided the original work is properly cited. 
These studies have revealed weak and inconsistent connection between individual's orientation and specific behavior within the restricted domain of marital interaction probably because of the very general locus of control measures used in these studies (Miller et al., 1986)

Recent reviews of the locus of control literature (Lefciyrt, 1982) have advocated the use of situation specific area locus of control measures for obtaining higher magnitude predictions of behavior. The marital locus of control has been defined operationally in the present study as score obtained by the husband or wife on the Miller marital locus of control scale.

\section{Studies on marital locus of control:}

Husain \& Grag (1985) studied 68 Hindu married couples residing in different localities of Aligarth city using the Miller marital locus of control scale. Point biserial correlation was calculated to determent the relationship between the scores of husbands and wives on this scale. The analysis indicated a significant positive relationship. The finding supported the similarity hypothesis, suggesting that similarity of personality is a characteristic of happily married couples. The results obtained seem to be promising and the MMLOC appears to be a viable measure to investigate the role of locus of control in the marital relationship.

Bugaighis et. Al., (1983) have studied the relationship between locus of control and marital satisfaction. In their study, older couples, 83 from rural and 98 from urban communities, completed measures of LOC and marital satisfaction. The findings indicated that the greater the internal loc for the wife, the higher marital satisfaction.

Doherty (1981) investigated the relationship between spouses' individual expectancies of internal vs. external control of reinforcement and their levels of marital dissatisfaction. The results suggested that external wives may believe that their dependency needs are not being met sufficiently by their relatively more self-contained internal husbands.

\section{OBJECTIVES:}

1) To investigate the role of marital locus of control of couples

2) To measure the marital adjustment of couples

\section{HYPOTHESIS:}

1) There is no significant difference between internal and external marital locus of control of couples.

2) There is no significant difference between locus of control and marital adjustment.

\section{TOOL AND PROCEDURE:}

1. Population: According to Gilford, Population consist all the situations, people and objects which have the same characteristics. In the present study, I have select couples (husbands and their wives) from Ahmadabad city.

2. Sample: Sample means the random selection of groups from population to get information about population. The sample consisted of 240 couples (120 husbands and 120 wives) from Ahmadabad city in urban area in Gujarat state. 
3. Variables: Independent variables : locus of control

Dependent variable: Marital adjustment

4. Tools:

1) Miller Marital Locus Of Control Scale - developed by Miller, Lef court and Ware (1983). It consists of 44 items in 6-point Likert type scale format. Its testretest reliability is 0.83 and validity is 0.69 .

2) The marital adjustment Questionnaire (Kumar \& Rohatgi, 1987) having 25 yesno type answers. The index of split-half reliability of MAQ is reported to be 0.70 and the validity against Singh's marital adjustment Inventory is 0.71 .

5. Statistical Technique: LSD test was applied to know the significant difference between the level of marital locus of control and marital adjustment.

\section{RESULTS:}

TABLE: 1 Means and Sample size of marital locus of control Groups

\begin{tabular}{|l|l|l|l|}
\hline & Internal & External & Total \\
\hline $\mathrm{N}$ & 120 & 120 & 240 \\
\hline $\mathrm{M}$ & 19.13 & 33.32 & \\
\hline
\end{tabular}

TABLE: 2 Results of LSD test on MLOC means.

\begin{tabular}{|l|l|l|l|}
\hline Pair & Means & Obtained & $\begin{array}{l}\text { Level of } \\
\text { significance }\end{array}$ \\
\hline & & Difference & \\
\hline I:E & $19.13: 33.32$ & 14.19 & 0.01 \\
\hline
\end{tabular}

$\mathrm{n}=120$ couples for $\mathrm{df}=239, \mathrm{MS}_{\mathrm{E}}=8.39, \mathrm{t} .05=1.96, \mathrm{t} .01=2.58$

The factor of marital locus of control has been found significant on marital adjustment score. Mean scores of internal and external groups are presented in table no: 1 and the results of LSD test are presented in table: 2. The closer examination of means and LSD test results in table:2 reveals that the internal locus of control group $M=19.13$ which emphasizes one's own efforts turned out to be less adjusted martially than external locus of control group, $\mathrm{M}=33.32$ which emphasizes less on outside forces such as luck, fate, change, etc. It would be seen from these table that the difference between two means is 14.19 , which is significant at 0.01 levels. 


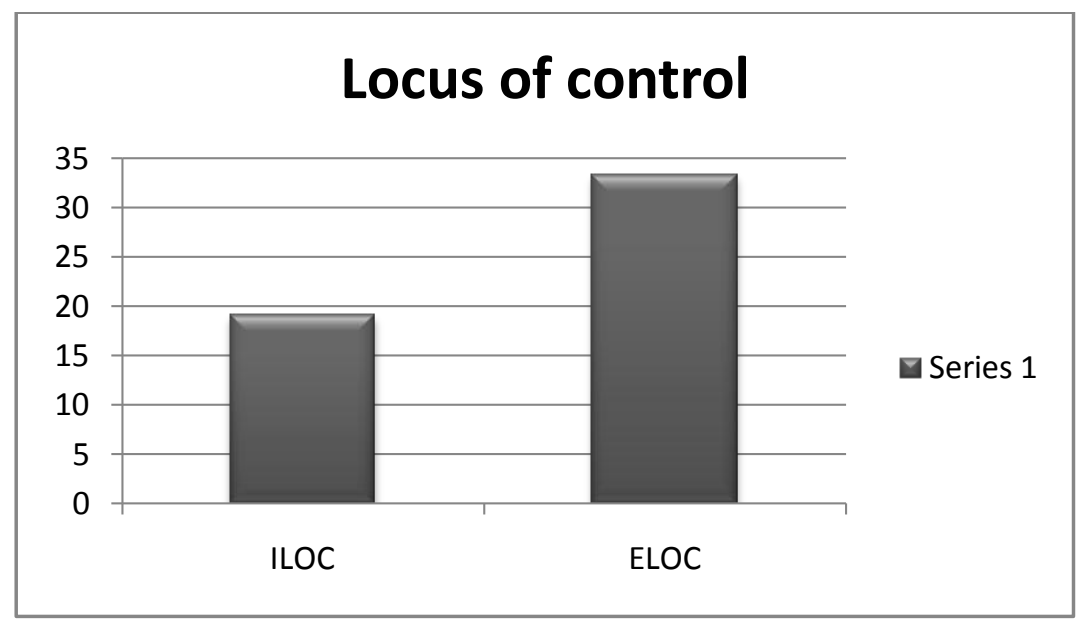

TABLE: 3Internal effect of MLOC on marital adjustment of couples (husbands and their wives)

\begin{tabular}{|l|l|l|l|l|}
\hline & & Husband & Wife & Total \\
\hline ILOC & $\mathrm{N}$ & 60 & 60 & 120 \\
\hline & $\mathrm{M}$ & 22.84 & 32.25 & \\
\hline ELOC & $\mathrm{N}$ & 60 & 60 & 120 \\
\hline & $\mathrm{M}$ & 41.22 & 18.79 & \\
\hline & \multicolumn{3}{|r|}{ Total } & 240 \\
\hline
\end{tabular}

TABLE: 4 Result of LSD test on internal effect of couples

\begin{tabular}{|l|l|l|l|l|}
\hline Pair & & Means & Obtained & $\begin{array}{l}\text { Level of } \\
\text { significance }\end{array}$ \\
\hline & & & Difference & \\
\hline ILOC & Husband: wife & $22.84: 32.25$ & 9.41 & 0.01 \\
\hline ELOC & Husband: wife & $41.22: 18.79$ & 22.43 & 0.01 \\
\hline
\end{tabular}

$\mathrm{n}=120$ couples for $\mathrm{df}=239, \mathrm{MS}_{\mathrm{E}}=8.39, \mathrm{t} .05=1.96, \mathrm{t} .01=2.58$

It may be seen from table: 3 that the effect of interaction between the variables of marital locus of control and marital adjustment of couples was found to be significant. Internal and external locus of control and husband and wife score also significantly interact each other. It is evident from table: 4 that significant mean difference existed between husband and wife with ILOC, the mean score of internal locus of control with husband, $M=41.22$ and internal locus of control with wife, $M=18.79$. The difference between two means is 22.43 which is significant at 0.01 level. It is also evident from table: 4 that significant mean difference existed between husband and wife with ELOC, the mean score of external locus of control with husband, $M=22.84$ and external locus of control with wife, $M=32.25$. The difference between two means is 9.41 which is significant at 0.01 level. 


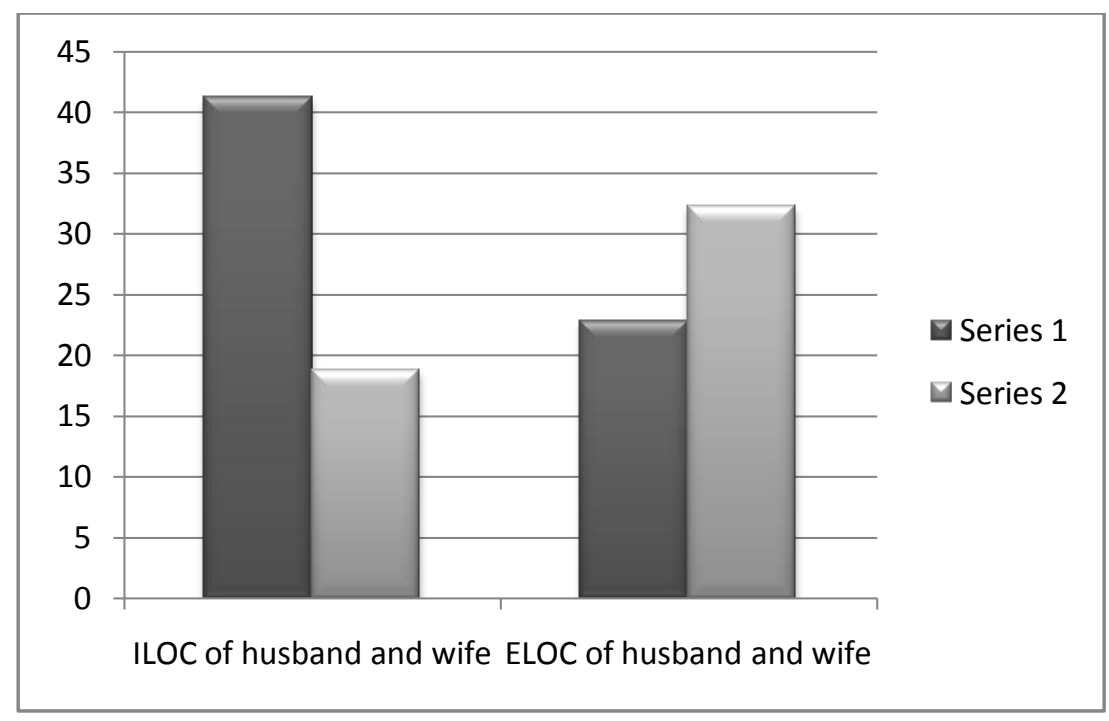

\section{DISCUSSION:}

The results obtained from statistical analysis of the data, it has been evident that the study has very clearly established the influence of factors viz., marital locus of control and marital adjustment of couples, fulfilling the main aim of the study as indicated by the title of the problem of the study. The results reveals that the internal locus of control group emphasizes one's own efforts turned out to be more adjusted martially than external locus of control group, emphasizes less on outside forces such as luck, fate, change, etc. It is also evident that significant mean difference existed between husband and wife with ILOC and significant mean difference existed between husband and wife with ELOC. Generally it is seen that when the time comes to talk about the marital adjustment, people mostly depend on their destiny, especially for women. Traditionally also it is believed that the marriages are made in heaven and therefore, again its success or failure depends more on the external forces than on internal abilities and efforts, is a common consideration. Even because of this, the adjustment of couples having external locus of control could be better.

\section{CONCLUSION:}

Marital locus of control was significant factor to marital adjustment. External locus of control group showed higher marital adjustment in comparison to internal locus of control group.

\section{LIMITATIONS, IMPLICATIONS AND SUGGESTIONS:}

As it would be observed from the discussion of results of the present investigation that the study had its own limitations and constraints that would restrict the investigator to draw inferences certainly or world guarantee the inferences in all circumstances. All care has been taken to use more adequate and advanced design and more refined statistical procedures have been utilized in the present study in order to extert more control over extraneous variance and minimize error 
variance have crept in, that might be responsible for some errors even in the present valid and more accurate results, neither totally comparable with nor in full agreement with the general theory of miller marital locus of control scale or sometimes showing dissensions or departures from findings of other relevant contemporary studies. The present study with its better control and methodology supports the theory about the marital locus of control and marital adjustment revels that there is a significant difference between the external locus of control and internal locus of control. In view of this, it is suggested that future researchers gaining experience from the present as well as earlier studies should continue their efforts to arrive at more information and more accurate results by using still more refined designs and statistical procedures available to avoid the likely error and also taking in consideration or planning beforehand a large sample or sufficient number of subjects in cells.

\section{REFERENCE:}

1. Contractor, B M (2003). Gujarati adaptation of Miller Marital Locus of Control Scale, Gujarat journal of psychology, 7, 40-44

2. Doherthy, W J (1981). Locus of control difference and marital dissatisfaction, Journal of Marriage and the family, 43, 369-377.

3. Gupta, Usha \& Singh, Pushpa (1982). An exploratory study of love and liking and type of marriages, Indian Journal of applied psychology, 1981 july, vol. 9(2): 92-97

4. Hiersm J M \& Heckel, R V (1999). Marital Locus of control and marital adjustment of working women, Journal of social psychology, 103, 313-315.

5. Sheth J S (2013). Marriage and adjustment. Raj publishing house, Jaipur 